\title{
Differential expression of the $L O X$ family genes in human colorectal adenocarcinomas
}

\author{
YOUNGHO KIM ${ }^{1}$, SEONAE ROH ${ }^{2}$, JUNG-YOUNG PARK ${ }^{1,3}$, \\ YANGSIK KIM $^{1}$, DONG HYUNG $\mathrm{CHO}^{2}$ and JIN CHEON KIM ${ }^{2}$
}

\author{
${ }^{1}$ Department of Biochemistry, School of Medicine, Wonkwang University, Iksan, Jeollabuk-Do; \\ ${ }^{2}$ Department of Surgery, University of Ulsan College of Medicine and Laboratory of Cancer Biology and Genetics, \\ Asan Institute for Life Sciences; ${ }^{3}$ School of Life Sciences and Biotechnology, Korea University, Seoul, Korea
}

Received May 19, 2009; Accepted June 26, 2009

DOI: 10.3892/or_00000502

\begin{abstract}
Lysyl oxidase (LOX) is an amine oxidase that catalyzes the cross-linking of collage or elastin in the extracellular matrix, regulating the tensile strength and structural integrity of connective tissues. Recently, four paralogues ( $L O X L, L O X L 2, L O X L 3$ and LOXL4) of LOX have been identified in humans, each containing the functional domains required for the amine oxidase activity toward collagen and elastin. Paradoxical roles of the LOX family members have been reported in various neoplastic tissues as tumor suppressors or promoters depending on tumor status and type. To address expression of the $L O X$ family genes in colorectal adenocarcinomas, we performed real-time PCR analysis with matched tumor/normal tissue specimens from 104 patients. The expression of the LOX family genes was not statistically associated with tumor location, stage, growth type, or differentiation status. However, upregulation of $L O X$, LOXL2 and LOXL4 was significantly correlated with absence of lymphovascular invasion $(\mathrm{P}=0.012,0.014$ and 0.005 , respectively), suggesting that the oxygen tension in or around the tumors may be an important regulator for the differential expression of LOX, LOXL2 and LOXL4 in colorectal cancer. Additionally, expression of $L O X$, but not the other $L O X$ family genes, was significantly upregulated in patients with a diffuse cytoplasmic expression pattern of CEA, indicating that $L O X$
\end{abstract}

Correspondence to: Dr Youngho Kim, Department of Biochemistry, School of Medicine, Wonkwang University, Sinyong-Dong 344-2, Iksan-City, Jeollabuk-Do 570-749, Korea E-mail: youngkim@wku.ac.kr

Dr Jin Cheon Kim, Department of Surgery, Asan Medical Center, Songpa-Gu, Seoul 138-736, Korea

E-mail: jckim@amc.seoul.kr

Key words: lysyl oxidase, lymphovascular invasion, colon carcinoma, carcinoembryonic antigen upregulation may be associated with increased invasiveness and metastatic potential in colorectal cancer.

\section{Introduction}

Lysyl oxidase (LOX) is a copper-dependent amine oxidase responsible for the development of lysine-derived crosslinkages in collagen and elastin in the extracellular matrices. LOX oxidatively deaminates the $\varepsilon$ amino groups of peptidyl lysine residues to $\alpha$-aminoadipic $\delta$-semialdehydes, and then the resulting aldehyde groups undergo spontaneous condensation with unreacted $\varepsilon$ amino groups or neighboring aldehyde groups to form cross-linkages within collagen and elastin fibers (reviewed in ref. 1). The LOX-mediated cross-linking of collagen and elastin is an essential step in maintaining structural integrity of connective tissues.

Four lysyl oxidase-like genes, LOXL, LOXL2, LOXL3 and LOXL4, have been identified in humans (2-5). The copper binding domain and the lysyl-tyrosyl-quinone (LTQ) residues that are required for the amine oxidase activity are strictly conserved at the C-terminus of all LOX family members. In addition to amine oxidase activity toward collagen and elastin, LOX has also been noted for several novel functions in tumorigenesis, cellular senescence and chemotaxis (reviewed in ref. 6). Lox expression was greatly downregulated in NIH 3T3 cells transformed by $H$-RAS but recovered in interferon-mediated revertants $(7,8)$. Blocking Lox expression led to contact inhibition, inability to proliferate in soft agar and tumor formation in nude mice, proposing a possible role of Lox as a tumor suppressor $(7,8)$. Additionally, increased LOX levels were detected at the invasion front adjacent to the infiltrating tumor cells in immunohistochemical analysis of breast and oral carcinoma, suggesting a defense mechanism by LOX against tumor infiltration (9).

However, perplexing expression patterns of $L O X$ and its human paralogues have been observed in various neoplastic tissues and cells. $L O X$ upregulation was detected in breast and renal cell carcinomas $(10,11)$, while $L O X$ downregulation was observed in prostate, bronchogenic, gastric, and head and neck squamous cell carcinomas (HNSCC) (12-15). LOXL2 expression was also downregulated in HNSCC (15) but upregulated in colon and esophageal and breast carcinomas 
(16,17). In addition, LOXL3 and LOXLA showed upregulation in breast cancer and HNSCC, respectively $(17,18)$. Of particular interest, upregulation of the LOX family genes have been reported in more invasive and metastatic tumors. The expression of LOX and LOXL2 was upregulated in highly invasive metastatic cells of breast carcinoma, while little to no expression was detected in non-metastatic cells of breast carcinoma (19). LOXL4 showed higher expression in invasive HNSCC tumors than primary ones (20). Additionally, LOXL2 showed enhanced immunostaining in the cytoplasm or perinuclear areas of laryngeal squamous cell carcinoma (21). Further, the enhanced expression of LOXL2 was significantly correlated with increased local recurrence and decreased survival (21). These findings, taken together, suggest that the $L O X$ family members may play paradoxical roles in suppression or progression of tumorigenesis depending on tumor status and type.

The purpose of this study was to explore the pathological relevance of the $L O X$ family genes to clinical parameters of cancer by assessing expression of $L O X$ and its paralogues in matched tumor/normal tissues from patients with colorectal adenocarcinoma. In our studies, LOX, LOXL2 and LOXL4 showed statistically significant upregulation in tumors without lymphovascular invasion (LVI), suggesting that the oxygen tension in or around the tumor tissues is an important regulator for the differential expression of these genes. We also report that $L O X$, but not the other $L O X$ family members, was significantly upregulated in tumors with diffuse cytoplasmic CEA expression compared to those with apicoluminal expression, indicating a possible functional role of LOX in increased invasiveness and metastatic potential.

\section{Materials and methods}

Tissue samples. Patients diagnosed with hereditary nonpolyposis colorectal cancer or familial adenomatous polyposis and its attenuated variants were excluded, as were those pre-operatively treated with chemoradiotherapy. After informed consent, tissues were acquired from primary tumors (5 $\mathrm{cm}$ proximal to the tumor margin) and normal tissues of 104 Korean colorectal adenocarcinoma patients who underwent curative operation at the Asan Medical Center (Seoul, Korea). All the tissue specimens were confirmed by histologic identification. Of these patients, 58 were male and 46 were female, with a mean age of 60 years (range: $33-82$ years). Among the patients, 28 had cancers of the right colon (cecum-splenic flexure of transverse colon) and 76 had cancers of the left colon (splenic flexure of transverse colonrectum). Using the tumor staging system of the American Joint Committee on Cancer (AJCC), 28 patients were in stage I, 37 were in stage II, 33 patients were in stage III and 6 were in stage IV. The median follow-up period was 19 months (range: 4-31 months). This study was conducted with the approval of the Institutional Review Board for Human Genetic and Genomic Research at the Asan Medical Center in accordance with the Helsinki declaration.

Reverse transcriptase ( $R T)$-PCR. Total RNA was extracted from the matched tumor and normal tissues of the patients, using the RNeasy kit (Qiagen) according to the manufacturer's instructions. Total cDNA was synthesized with $0.5 \mu \mathrm{g}$ of the extracted RNA, using $M-M L V$ Reverse Transcriptase (Promega) and oligo (dT)15 (Promega) in a $20 \mu \mathrm{l}$ reaction. PCR amplification was performed using ExTag polymerase (Takara) with primers specific to each member of the LOX family. The primer sequences and annealing temperatures are listed in Table I. The PCR primers were derived from the 3' UTR sequences of the LOX family genes, where little sequence conservation was observed among the $L O X$ family members. The reaction mixture was subjected to 30 cycles of $94^{\circ} \mathrm{C}$ for $20 \mathrm{sec}, 55-59^{\circ} \mathrm{C}$ for $20 \mathrm{sec}$ and $72^{\circ} \mathrm{C}$ for $30 \mathrm{sec}$ with a pre-denaturation at $94^{\circ} \mathrm{C}$ for $4 \mathrm{~min}$ and a final extension at $72^{\circ} \mathrm{C}$ for $7 \mathrm{~min}$. GAPDH was used for an internal control. The amplified PCR products were then analyzed by electrophoresis on $2 \%$ agarose gels. Relative quantitation of the PCR amplicons was performed using Molecular Imaging Software, version 4.5 (Kodak).

Real-time quantitative PCR. The primers used for RT-PCR were also used for real-time PCR analysis. The TaqMan probes were labeled with a 5' FAM reporter and a 3' BHQ quencher (Integrated DNA Technologies). Real-time PCR amplification was performed in duplicate using the Chromo $4^{\mathrm{TM}}$ real-time system (MJ Research). PCR was performed in a total volume of $10 \mu \mathrm{l}$, containing $1 \mu 1$ of cDNA, $5 \mu 1$ of $2 \mathrm{x}$ Premix EX Tag ${ }^{\mathrm{TM}}$ (Takara), 10 pmole of each primer and a TaqMan probe. The probe sequences are listed in Table I. The reaction mixture was subjected to 35 cycles of $95^{\circ} \mathrm{C}$ for $15 \mathrm{sec}$ and $55-59^{\circ} \mathrm{C}$ for $60 \mathrm{sec}$ with a pre-denaturation at $95^{\circ} \mathrm{C}$ for 15 min. Commercially available $G A P D H$ primers and probes (Applied Biosystems) were used for an internal control. A cDNA-free reaction was also included as a negative control in each reaction. The relative expression of the $L O X$ family genes was determined using the $\Delta \Delta \mathrm{Ct}$ method. The $\mathrm{Ct}$ value was defined as the threshold PCR cycle at which the amplified PCR product was first detected.

Immunohistochemistry. Paraffin-embedded tissue cores of carcinomas were used for the construction of tissue blocks for tissue microarray using a precision instrument (Beecher Instrument Inc.) Tissue array blocks containing core cylinders were subjected to immune staining with a monoclonal antibody to CEA (American Type Culture Collection) and labeled by the streptavidin-biotin method using the LSAB ${ }^{\circledR}$ kit (Dako). For CEA, apicoluminal localization or lack of staining was interpreted as negative, whereas diffuse cytoplasmic staining was considered positive. All immunohistochemical staining results were confirmed by two separate pathologists.

Statistical methods. Differential expression of $L O X$ and its paralogues was compared with levels of various clinical and molecular parameters by cross-table analysis using Fisher's exact test. The potential parameters were verified by multivariate analysis using logistic regression. Numerical values for independent variables were tested by unpaired Student's t-test or ANOVA with least-squares deviation verification. All statistical analyses were performed using SPSS software (ver.13, SPSS Inc.). A P-value $<0.05$ was considered statistically significant. 
Table I. Sequences of primers and probes used for RT-PCR and real-time PCR.

\begin{tabular}{|c|c|c|c|}
\hline Gene & Primer or Probe & Sequence & Annealing temperature \\
\hline$L O X$ & $\begin{array}{l}\text { Forward primer } \\
\text { Reverse primer } \\
\text { Probe }\end{array}$ & $\begin{array}{l}\text { 5'-GAACGCTTAAGTCATCATTACTTG-3' } \\
\text { 5'-TGGCTCATTCATTTAGATAATACTGA-3' } \\
\text { 5'-TTGCACTACAATTTCAAAAGGAACATG-3' }\end{array}$ & $56^{\circ} \mathrm{C}$ \\
\hline$L O X L$ & $\begin{array}{l}\text { Forward primer } \\
\text { Reverse primer } \\
\text { Probe }\end{array}$ & $\begin{array}{l}\text { 5'-AATCTCTCCCCTTCCAAAGCAG-3' } \\
\text { 5'-AGCTCTGTGGTATGGCCAAAGT-3' } \\
\text { 5'-AAACCACAGGGATTCCGGACGCCA-3' }\end{array}$ & $57^{\circ} \mathrm{C}$ \\
\hline LOXL2 & $\begin{array}{l}\text { Forward primer } \\
\text { Reverse primer } \\
\text { Probe }\end{array}$ & $\begin{array}{l}\text { 5'-GTCTGTGTTTCCTTTGACCCA-3' } \\
\text { 5'-GATTATGACTCCTGTTCCGTTACT-3' } \\
\text { 5'-TTGTGATCTCCTTAGATTGCTTCTCCCA-3' }\end{array}$ & $55^{\circ} \mathrm{C}$ \\
\hline LOXL3 & $\begin{array}{l}\text { Forward primer } \\
\text { Reverse primer } \\
\text { Probe }\end{array}$ & $\begin{array}{l}\text { 5'-ATGTCAGCAACCGCACTCAT-3' } \\
\text { 5'-AGTCAGGTGCTGCTCTTTGT-3' } \\
\text { 5'-ATGGGAATCTTTGCTCCCAGGCCCA-3' }\end{array}$ & $57^{\circ} \mathrm{C}$ \\
\hline LOXLA & $\begin{array}{l}\text { Forward primer } \\
\text { Reverse primer } \\
\text { Probe }\end{array}$ & $\begin{array}{l}\text { 5'-AGGGCCTCTGCCAAGGAAATAA-3' } \\
\text { 5'-ATCAAGCAGGAATGGTGGCCTT-3' } \\
\text { 5'-TACCTGGCAGGCAGTCTGCTCTCTCT-3' }\end{array}$ & $59^{\circ} \mathrm{C}$ \\
\hline
\end{tabular}

Table II. Comparative analysis of the $L O X$ family gene expression with clinicopathologic parameters.

\begin{tabular}{|c|c|c|c|c|c|}
\hline \multirow{2}{*}{$\begin{array}{l}\text { Clinicopathological parameters } \\
\text { (No. of patients) }\end{array}$} & \multicolumn{5}{|c|}{$\begin{array}{l}\text { Percentage of tumors with a } 2^{\Delta \Delta C t} \text { value }>1 \text {-fold } \\
\text { (P-value) }\end{array}$} \\
\hline & $L O X$ & $L O X L$ & $L O X L 2$ & $L O X L 3$ & $L O X L A$ \\
\hline $\begin{array}{l}\text { Location, } \\
\text { right vs. left rectum }(28 / 76)\end{array}$ & $\begin{array}{l}42.9 / 43.4 \\
(0.57)\end{array}$ & $\begin{array}{l}42.9 / 46.1 \\
(0.474)\end{array}$ & $\begin{array}{c}50 / 50 \\
(0.587)\end{array}$ & $\begin{array}{c}46.4 / 51.3 \\
(0.413)\end{array}$ & $\begin{array}{l}42.9 / 42.1 \\
(0.559)\end{array}$ \\
\hline $\begin{array}{l}\text { Largest diameter, } \\
\leq 4 \mathrm{~cm} \text { vs. }>4 \mathrm{~cm}(39 / 65)\end{array}$ & $\begin{array}{c}35.9 / 47.7 \\
(0.166)\end{array}$ & $\begin{array}{c}33.3 / 52.3 \\
(0.046)^{\mathrm{a}}\end{array}$ & $\begin{array}{l}43.6 / 53.8 \\
(0.209)\end{array}$ & $\begin{array}{l}46.2 / 52.3 \\
(0.343)\end{array}$ & $\begin{array}{l}35.9 / 46.2 \\
(0.206)\end{array}$ \\
\hline $\begin{array}{l}\text { AJCC stage, } \\
\text { I + II vs. III + IV (53/51) }\end{array}$ & $\begin{array}{l}50.9 / 35.3 \\
(0.079)\end{array}$ & $\begin{array}{l}49.1 / 41.2 \\
(0.271)\end{array}$ & $\begin{array}{l}54.7 / 45.1 \\
(0.216)\end{array}$ & $\begin{array}{l}56.6 / 43.1 \\
(0.12)\end{array}$ & $\begin{array}{l}47.2 / 37.3 \\
(0.205)\end{array}$ \\
\hline $\begin{array}{l}\text { Growth type, } \\
\text { expanding vs. infiltrative }(86 / 18)\end{array}$ & $\begin{array}{l}44.2 / 38.9 \\
(0.443)\end{array}$ & $\begin{array}{l}47.7 / 33.3 \\
(0.198)\end{array}$ & $\begin{array}{l}52.3 / 38.9 \\
(0.219)\end{array}$ & $\begin{array}{l}50.0 / 50.0 \\
(0.602)\end{array}$ & $\begin{array}{l}45.3 / 27.8 \\
(0.133)\end{array}$ \\
\hline $\begin{array}{l}\text { Differentiation, }(91 / 13) \\
\text { WD or MD vs. PD or mucinous }\end{array}$ & $\begin{array}{l}42.9 / 46.2 \\
(0.526)\end{array}$ & $\begin{array}{l}45.1 / 46.2 \\
(0.585)\end{array}$ & $\begin{array}{l}49.5 / 53.8 \\
(0.500)\end{array}$ & $\begin{array}{l}49.5 / 53.8 \\
(0.500)\end{array}$ & $\begin{array}{l}41.8 / 46.2 \\
(0.495)\end{array}$ \\
\hline $\begin{array}{l}\text { Synchronous adenoma, } \\
\text { absence vs. presence }(64 / 40)\end{array}$ & $\begin{array}{l}48.4 / 35 \\
(0.126)\end{array}$ & $\begin{array}{l}43.8 / 47.5 \\
(0.431)\end{array}$ & $\begin{array}{l}53.1 / 45.0 \\
(0.273)\end{array}$ & $\begin{array}{l}53.1 / 45.0 \\
(0.273)\end{array}$ & $\begin{array}{l}43.8 / 40.0 \\
(0.432)\end{array}$ \\
\hline $\begin{array}{l}\text { Lymphovascular invasion, } \\
\text { absence vs. presence }(75 / 29)\end{array}$ & $\begin{array}{c}50.7 / 24.1 \\
(0.012)^{\mathrm{a}}\end{array}$ & $\begin{array}{l}50.7 / 31.0 \\
(0.056)\end{array}$ & $\begin{array}{l}57.3 / 31.0 \\
(0.014)^{\mathrm{a}}\end{array}$ & $\begin{array}{c}52.0 / 44.8 \\
(0.331)\end{array}$ & $\begin{array}{c}50.7 / 20.7 \\
(0.005)^{\mathrm{a}}\end{array}$ \\
\hline
\end{tabular}

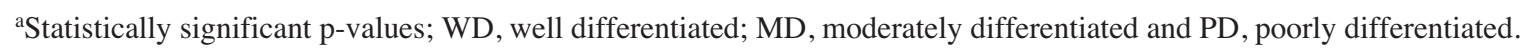

\section{Results}

Expression of the LOX family genes in colorectal tumors. Expression of the LOX family genes was assessed by the comparative $\Delta \Delta \mathrm{Ct}$ method in which $\Delta \mathrm{Ct}$ was defined as a difference in the $\mathrm{Ct}$ values between one of the $L O X$ family genes and the GAPDH control $\left[\triangle \mathrm{Ct}=(\mathrm{Ct})_{\mathrm{LOX}}-(\mathrm{Ct})_{\mathrm{GAPDH}}\right]$. $\Delta \Delta \mathrm{Ct}$ was defined as a difference in the $\Delta \mathrm{Ct}$ values between a normal tissue and a tumor tissue of the same patient
$\left[\Delta \Delta \mathrm{Ct}=(\Delta \mathrm{Ct})_{\text {normal }}-(\Delta \mathrm{Ct})_{\text {tumor }}\right)$. The $\mathrm{N}$-fold difference in the expression of the $L O X$ family genes was expressed as $2^{\Delta \Delta \mathrm{Ct}}$. $2^{\Delta \Delta \mathrm{Ct}}$ values over 1-fold indicate upregulation of the tested $L O X$ family gene in a tumor tissue compared to a normal counterpart of the same patient. Mean values of $2^{\Delta \Delta C \mathrm{Ct}}$ were $2.79 \pm 0.69$ (mean \pm SEM) for $L O X, 2.88 \pm 0.65$ for $L O X L$, $5.99 \pm 1.74$ for $L O X L 2,5.70 \pm 1.6$ for $L O X L 3$ and $4.21 \pm 0.86$ for LOXLA. The $2^{\Delta \Delta \mathrm{Ct}}$ values of all the LOX family genes were closely correlated between any two of them $(R=0.494-0.959$, 

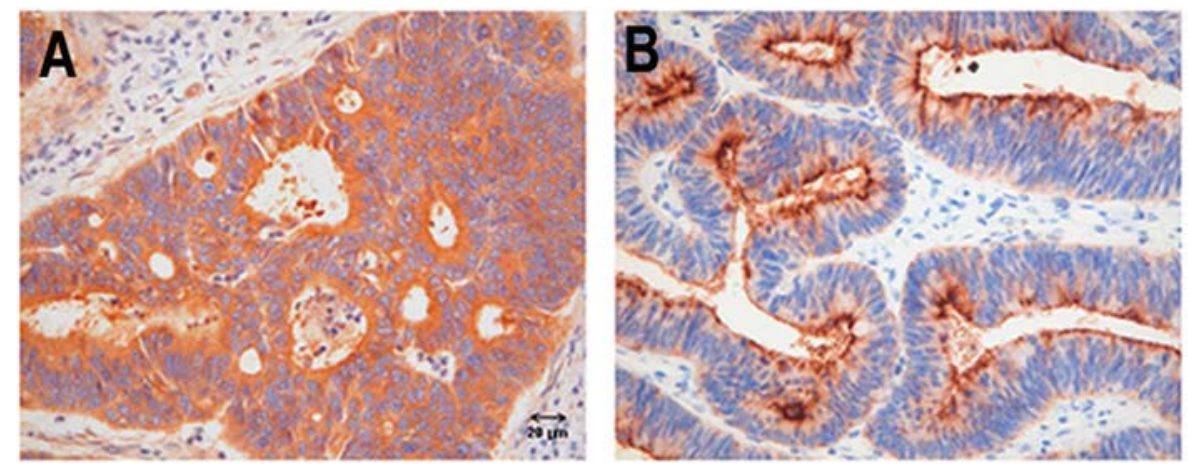

Figure 1. Typical examples of immunohistochemical staining with CEA showing a diffuse cytoplasmic distribution (A) or an apicoluminal pattern (B) in patients with colorectal adenocarcinomas.

A Diffuse-Cytoplasmic CEA

$\begin{array}{llll}\mathrm{P} 1 & \mathrm{P} 2 & \mathrm{P} 3 & \mathrm{P} 4 \\ \mathrm{~N} & \mathrm{~N} & \mathrm{~N} & \mathrm{~N} \\ -\infty & - & -\cdots \\ -\cdots-\cdots-\cdots\end{array}$

B 즘

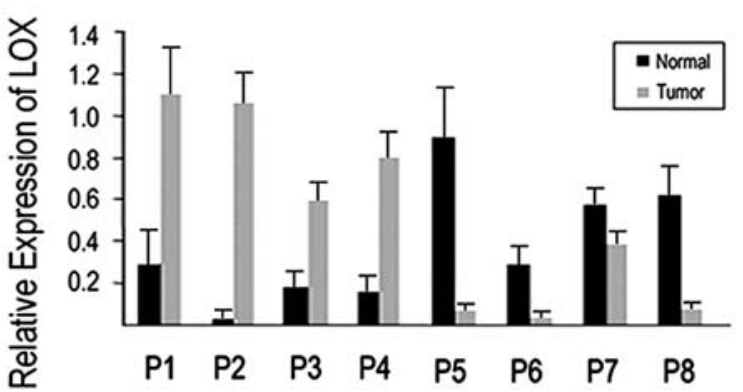

Figure 2. Relative expression of $L O X$ compared to the cellular patterns of CEA immunoreactivity. (A) Typical examples of RT-PCR analysis of $L O X$ with the matched tumor/normal tissue samples. P1 to P8 represent different patients with colon carcinoma. $\mathrm{N}$ and $\mathrm{T}$ stand for normal and tumor tissues of the matched pairs, respectively. P1 to P4 patients showed a diffuse cytoplasmic expression pattern of CEA, whereas P5 to P8 patients showed an apicoluminal expression pattern of CEA. (B) Quantitative analysis of $L O X$ expression. The intensity of the PCR amplicons of $L O X$ was expressed as a densitometric ratio to the intensity of the GAPDH amplicons. All assays were repeated in triplicate. The average is shown with error bars representing the standard deviation.

$\mathrm{P}<0.0001)$. In approximately half of the cases tested, the $2 \Delta \Delta \mathrm{c}$ values were $>1$-fold ( $42.3 \%$ for $L O X, 45.2 \%$ for $L O X L, 50.0 \%$ for $L O X L 2,50.0 \%$ for $L O X L 3$ and $42.3 \%$ for LOXL4). The $2^{\Delta \Delta C t}$ values did not differ in gender and age.

Association with clinicopathological parameters. The patients showing $>1$-fold of $2^{\Delta \Delta C t}$ were subjected to association studies with clinicopathological parameters (Table II). Upregulation of the $L O X$ family genes was not significantly associated with location, AJCC stage, growth type, or differentiation status. In addition, the presence or absence of synchronous adenoma did not show any significant correlation with the upregulation of the LOX family genes either. However, in analysis with tumor diameter, LOXL showed a close correlation with larger tumors $(>4 \mathrm{~cm} ; \mathrm{P}=0.046)$, while the other $L O X$ family genes did not present any significant associations (Table II). Of particular interest, tumors without LVI were significantly correlated with upregulation of $L O X$, LOXL2 and LOXL4 ( $\mathrm{P}=0.012,0.014$ and 0.005 , respectively); however, association of LVI with LOXL and LOXL3 was not statistically significant.

Association with carcinoembryonic antigen (CEA). We have previously reported that CEA, a well studied diagnostic marker of colorectal cancer, shows a diffuse cytoplasmic expression pattern rather than an apicoluminal expression pattern in more invasive colorectal tumors (22). In the present studies, the expression patterns of CEA depending on invasiveness were also confirmed in the colorectal tumor tissues (Fig. 1). In analysis of the $L O X$ family genes with the CEA expression patterns, the $2^{\Delta \Delta C t}$ values of $L O X$ were significantly greater in the tumor tissues with diffuse cytoplasmic expression of CEA compared to those with apicoluminal expression (4.36 \pm 1.4 vs. $1.44 \pm 0.3, \mathrm{P}=0.038$ ) (Fig. 2). The other $L O X$ family members, in contrast, did not show any significant associations with CEA expression patterns. None of the $L O X$ family members showed any significant correlations with preoperative serum CEA levels (data not shown).

\section{Discussion}

Microarray studies have previously revealed that the expression of $L O X$ is consistently upregulated in hypoxic human tumor cells (23). Further, LOX was identified to play an essential role in hypoxia-induced metastasis of breast and head and neck carcinomas (24). Hypoxia is caused by low oxygen tension in the surrounding tissues due to inadequate blood supply and hypoxic tumor cells are more metastatic and resistant to chemotherapy (25). In our results, upregulation of $L O X$, LOXL2 and LOXL4 was remarkably more frequent in the tumors without LVI than those with LVI. In tumors without LVI, blood supply to the tumor cells is limited, resulting in relatively lower oxygen tension around the tumor cells (26). Our results suggest that oxygen deprivation in the absence of LVI may enhance the expression of not only $L O X$ but also LOXL2 and LOXL4 in colorectal tumors. A hypoxia-response element (HRE) present in the promoter region of the $L O X$ gene was known to regulate the $L O X$ upregulation through 
an interaction with hypoxia-inducible factor-1 (HIF-1) (24). Further studies on identification and functional characterization of HREs in the 5'-upstream regions of LOXL2 and LOXL4 or interactions with the trans-acting HIF-1 may reveal the regulatory mechanisms for the upregulation of these genes in hypoxic tumor cells.

CEA, a $180 \mathrm{kDa}$ glycoprotein, is a member of the immunoglobulin supergene family that is comprised of at least 29 genes (27). Elevated serum levels of CEA are clinically associated with induction of metastasis and suppression of anoikis, a form of apoptosis caused by detachment from extracellular matrices, in colorectal carcinomas (28). CEA shows a diffuse-cytoplasmic expression pattern rather than an apicoluminal pattern in more invasive and metastatic neoplastic cells of colorectal tumors (22). In our studies, $L O X$ upregulation was significantly greater in tumors with diffuse cytoplasmic CEA expression than those with absent or apicoluminal expression, further supporting the role for LOX in metastasis progression. CEA upregulation has been known to enhance the interaction of integrin and fibronectin, leading to increased adhesion of the CEAexpressing cells to the extracellular matrix and then resulting in suppression of anoikis (29). LOX also affects the integrinfibronectin interaction through binding to fibronectin and the LOX-fibronectin interaction is involved in regulating proteolytic activation of the amine oxidase activity of LOX (30). These similar features of CEA and LOX in integrin signaling, together with our findings on the $L O X$ upregulation in more invasive tumor tissues, suggest that LOX and CEA may exert a synergistic effect on the progression of metastasis, although the functional significance of their co-expression needs to be further elucidated.

In conclusion, upregulation of the $L O X$ family genes was not significantly associated with location, stage, differentiation status, or growth type of colorectal adenocarcinomas. However, upregulation of LOX, LOXL2 and $L O X L$ was strongly correlated with the absence of LVI, suggesting that expression of these genes may be regulated by oxygen tension surrounding colorectal tumors. Due to limited follow-up periods, we could not elucidate the correlation of these $L O X$ family genes with metastasis of colorectal tumors. Further longitudinal studies are required to address the correlation of the differential expression of the $L O X$ family genes with local recurrence, survival and invasiveness in colorectal carcinomas.

\section{Acknowledgements}

This study was supported by the Korea Research Foundation Grant funded by the Korean Government (MOEHRD, Basic Research Promotion Fund) (KRF-2008-521-C00169) and grants from the Korea Health Care Technology R\&D projects, Ministry of Health, Welfare and Family Affairs, Republic of Korea (grant numbers: A080041 and A062254).

\section{References}

1. Smith-Mungo LI and Kagan HM: Lysyl oxidase: Properties, regulation andmultiple functions in biology. Matrix Biol 16: 387-398, 1997.

2. Kim Y, Boyd CD and Csiszar K: A new gene with sequence and structural similarity to the gene encoding human lysyl oxidase. J Biol Chem 270: 7176-7182, 1995.
3. Jourdan-Le Saux C, Tronecker H, Bogic L, Bryant-Greenwood GD, Boyd CD and Csiszar K: The LOXL2 gene encodes a new lysyl oxidase-like protein and is expressed at high levels in reproductive tissues. J Biol Chem 274: 12939-12944, 1999.

4. Maki JM and Kivirikko KI: Cloning and characterization of a fourth human lysyl oxidase isoenzyme. Biochem J 355: 381-387, 2001.

5. Asuncion L, Fogelgren B, Fong KS, Fong SF, Kim Y and Csiszar K: A novel human lysyl oxidase-like gene (LOXL4) on chromosome 10q24 has an altered scavenger receptor cysteine rich domain. Matrix Biol 20: 487-491, 2004.

6. Csiszar K: Lysyl oxidase: a novel multifunctional amine oxidase family. Prog Nucleic Acid Res Mol Biol 70: 1-32, 2001.

7. Contente S, Kenyon K, Rimoldi D and Friedman RM: Expression of gene rrg is associated with reversion of NIH $3 \mathrm{~T} 3$ transformed by LTR-c-H-ras. Science 249: 796-798, 1990.

8. Kenyon K, Contente S, Trackman PC, Tang J, Kagan HM and Friedman RM: Lysyl oxidase and rrg messenger RNA. Science 253: 802, 1991 .

9. Peyrol S, Raccurt M, Gerard F, Gleyzal C, Grimaud JA and Sommer P: Lysyl oxidase gene expression in the stromal reaction to in situ and invasive ductal breast carcinoma. Am J Pathol 150: 497-507, 1997.

10. Kirschmann DA, Seftor EA, Nieva DR, Mariano EA and Hendrix MJ: Differentially expressed genes associated with the metastatic phenotype in breast cancer. Breast Cancer Res Treat 55: 127-136, 1999.

11. Stassar MJ, Devitt G, Brosius M, Rinnab L, Prang J, Schradin T, Simon J, Petersen S, Kopp-Schneider A and Zoller M: Identification of human renal cell carcinoma associated genes by suppression subtractive hybridization. Br J Cancer 85: $1372-1382,2001$

12. Ren C, Yang G, Timme TL, Wheeler TM and Thompson TC: Reduced lysyl oxidase messenger RNA levels in experimental and human prostate cancer. Cancer Res 58: 1285-1290, 1998.

13. Woznick AR, Braddock AL, Dulai M, Seymour ML, Callahan RE, Welsh RJ, Chmielewski GW, Zelenock GB and Shanley CJ: Lysyl oxidase expression in bronchogenic carcinoma. Am J Surg 189: 297-301, 2005.

14. Kaneda A, Wakazono K, Tsukamoto T, Watanabe N, Yagi Y, Tatematsu M, Kaminishi M, Sugimura T and Ushijima T: Lysyl oxidase is a tumor suppressor gene inactivated by methylation and loss of heterozygosity in human gastric cancers. Cancer Res 64: 6410-6415, 2004.

15. Rost T, Pyritz V, Rathcke IO, Gorogh T, Dunne AA and Werner JA: Reduction of LOX- and LOXL2-mRNA expression in head and neck squamous cell carcinomas. Anticancer Res 23: $1565-1573,2003$

16. Fong SF, Dietzsch E, Fong KS, Hollosi P, Asuncion L, He Q, Parker MI and Csiszar K: Lysyl oxidase-like 2 expression is increased in colon and esophageal tumors and associated with less differentiated colon tumors. Genes Chromosomes Cancer 46: 644-655, 2007.

17. Peinado H, del Carmen Iglasias-de la Cruz M, Olmeda D, Csiszar K, Fong KSK, Vega S, Nieto MA, Cano A and Portillo F: A molecular role for lysyl oxidase-like 2 enzyme in snail regulation and tumor progression. EMBO J 24: 3446-3458, 2005.

18. Holtmeier C, Gorogh T, Beier U, Meyer J, Hoffmann M, Gottschlich S, Heidorn K, Ambrosch P and Maune S: Overexpression of a novel lysyl oxidase-like gene in human head and neck squamous cell carcinomas. Anticancer Res 23: 2585-2591, 2003.

19. Kirschmann DA, Seftor EA, Fong SF, Nieva DR, Sullivan CM, Edwards EM, Sommer P, Csiszar K and Hendrix MJ: A molecular role for lysyl oxidase in breast cancer invasion. Cancer Res 62: 4478-4483, 2002

20. Gorogh T, Weise JB, Holtmeier C, Rudolph P, Hedderich J, Gottschlich S, Hoffmann M, Ambrosch P and Csiszar K: Selective upregulation and amplification of the lysyl oxidase like-4 (LOXL4) gene in head and neck squamous cell carcinoma. J Pathol 212: 74-82, 2007.

21. Peinado H, Moreno-Bueno G, Hardisson D, Pérez-Gómez E, Santos V, Mendiola M, de Diego JI, Nistal M, Quintanilla M, Portillo F and Cano A: Lysyl oxidase-like 2 as a new poor prognosis marker of squamous cell carcinoma. Cancer Res 68: 4541-4550, 2008.

22. Kim JC, Han MS, Lee HK, Kim WS, Park SK, Park KC, Bodmer WF, Rowan AJ and Kim OJ: Distribution of carcinoembryonic antigen and biologic behavior in colorectal carcinoma. Dis Colon Rectum 42: 640-648, 1999. 
23. Denko NC, Fontana LA, Hudson KM, Sutphin PD, Raychaudhuri S, Altman R and Giaccia AJ: Investigating hypoxic tumor physiology through gene expression patterns. Oncogene 22: 5907-5914, 2003.

24. Erler JT, Bennewith KL, Nicolau M, Dornhofer N, Kong C, Le QT, Chi JT, Jeffrey SS and Giaccia AJ: Lysyl oxidase is essential for hypoxia-induced metastasis. Nature 440: 1222-1226, 2006.

25. Cairns RA, Khokha R and Hill RP: Molecular mechanisms of tumor invasion and metastasis: an integrated view. Curr Mol Med 3: 659-671, 2003.

26. Ohhashi T, Mizuno R, Ikomi F and Kawai Y: Current topics of physiology and pharmacology in the lymphatic system. Pharmacol Ther 105: 165-188, 2005 .

27. Beauchemin N, Draber P, Dveksler G, Gold P, Gray-Owen S, Grunert F, Hammarström S, Holmes KV, Karlsson A, Kuroki M, Lin SH, Lucka L, Najjar SM, Neumaier M, Obrink B, Shively JE, Skubitz KM, Stanners CP, Thomas P, Thompson JA, Virji M, von Kleist S, Wagener C, Watt S and Zimmermann W: Redefined nomenclature for members of the carcinoembryonic antigen family. Exp Cell Res 252: 243-249, 1999.
28. Samara RN, Laguinge LM and Jessup JM: Carcinoembryonic antigen inhibits anoikis in colorectal carcinoma cells by interfering with TRAIL-R2 (DR5) signaling. Cancer Res 67: 4774-4782, 2007.

29. Ordonez C, Zhai AB, Camacho-Leal P, Demarte L, Fan MM and Stanners CP: GPI-anchored CEA family glycoproteins CEA and CEACAM6 mediate their biological effects through enhanced integrin alpha5beta1-fibronectin interaction. J Cell Physiol 210: 757-765, 2007.

30. Fogelgren B, Polgár N, Szauter KM, Ujfaludi Z, Laczkó R, Fong KS and Csiszar K: Cellular fibronectin binds to lysyl oxidase with high affinity and is critical for its proteolytic activation. J Biol Chem 280: 24690-24697, 2005. 